\title{
High-Strength Low-Carbon Ferritic Steel Containing Cu-Fe-Ni-Al-Mn Precipitates
}

\author{
SEMYON VAYNMAN, DIETER ISHEIM, R. PRAKASH KOLLI, SHRIKANT P. BHAT, \\ DAVID N. SEIDMAN, and MORRIS E. FINE
}

\begin{abstract}
An investigation of a low-carbon, $\mathrm{Fe}-\mathrm{Cu}$-based steel, for Naval ship hull applications, with a yield strength of $965 \mathrm{MPa}$, Charpy V-notch absorbed impact-energy values as high as $74 \mathrm{~J}$ at $-40{ }^{\circ} \mathrm{C}$, and an elongation-to-failure greater than $15 \mathrm{pct}$, is presented. The increase in strength is derived from a large number density (approximately $10^{23}$ to $10^{24} \mathrm{~m}^{-3}$ ) of copper-iron-nickelaluminum-manganese precipitates. The effect on the mechanical properties of varying the thermal treatment was studied. The nanostructure of the precipitates found within the steel was characterized by atom-probe tomography. Additionally, initial welding studies show that a brittle heat-affected zone is not formed adjacent to the welds.
\end{abstract}

DOI: $10.1007 / \mathrm{s} 11661-007-9417-\mathrm{x}$

(C) The Minerals, Metals \& Materials Society and ASM International 2008

\section{INTRODUCTION}

ApProximATELY 20 years ago, the United States Navy developed a high-strength low-alloy (HSLA) steel, denoted HSLA-100, with a yield strength of $100 \mathrm{ksi}$ $(689 \mathrm{MPa})$, as a replacement for HY-100 steel to reduce fabrication costs in ship construction. ${ }^{[1-4]}$ HSLA-100 possesses similar strength and toughness values as HY100 , but because of the reduced nominal carbon content, it is weldable without preheat, thereby reducing fabrication costs. ${ }^{[3-5]}$ To compensate for the decrease in strength on reducing the $\mathrm{C}$ concentration, $\mathrm{Cu}$ was added to HSLA-100 for precipitation strengthening, whereas $\mathrm{Cr}$, $\mathrm{Ni}$, and Mo were added to increase hardenability. ${ }^{[2-7]}$

The thermal processing of HSLA-100, a solutionizing (austenitizing) and quenching step followed by tempering at $620{ }^{\circ} \mathrm{C}$ to $690{ }^{\circ} \mathrm{C}$, produced a tempered martensitic steel containing Cu precipitates. ${ }^{[2-4]}$ Studies by Foley et $a l .{ }^{[8,9]}$ have demonstrated that tempering of HSLA100 overages the $\mathrm{Cu}$ precipitates, thereby reducing their strengthening contribution.

Earlier research on steels alloyed with $\mathrm{Cu}$, however, showed that significant strengthening could be attained without tempering. ${ }^{[10-13]}$ To develop a precipitationstrengthened ferritic variant of HSLA-100 steel, Mo and $\mathrm{Cr}$ were removed, reducing hardenability, and the thermal processing was simplified to hot rolling followed by air cooling. These changes produced a ferritic HSLA

SEMYON VAYNMAN, Research Professor and MORRIS E. FINE, Professor, Member of Graduate Faculty, Department of Materials Science and Engineering, and DIETER ISHEIM, Research Assistant Professor, and DAVID N. SEIDMAN, W.P. Murphy Professor, Department of Materials Science and Engineering and Northwestern University Center for Atom-Probe Tomography (NUCAPT), are with Northwestern University Evanston, IL 602083108. Contact email: svaynman@northwestern.edu R. PRAKASH KOLLI, Senior Metallurgist, is with Global Customer Analytical, Nalco Company, Naperville, IL 60563 and SHRIKANT P. BHAT, Manager, is with ArcelorMittal Steel Global Research \& Development, East Chicago, IN 46312.

Manuscript submitted May 11, 2007.

Article published online January 9, 2008 plate steel with a yield strength in excess of $482 \mathrm{MPa}$ (70 ksi), a Charpy V-notch (CVN) absorbed impactenergy better than $136 \mathrm{~J}$ (100 ft-lbs) at $-40{ }^{\circ} \mathrm{C}$, improved weldability, and enhanced atmospheric corrosion resistance.$^{[8,14-18]}$ This steel, ASTM A710 grade B, was used in construction of a demonstration bridge in northern Illinois. The body-centered-cubic (bcc) nanoscale $\mathrm{Cu}$ precipitates within the steel are coherent with the matrix providing significant precipitation strengthening. Goodman et al. first documented this in a binary $\mathrm{Fe}-\mathrm{Cu}$ steel many years ago by using field-ion and atom-probe microscopies. ${ }^{[19,20]}$

Additional increases in yield strength were achieved by changing the thermal processing to hot rolling followed by quenching into water and subsequently isothermal aging. The result was a high-strength lowcarbon (HSLC) steel with yield strengths of approximately $700 \mathrm{MPa}(100 \mathrm{ksi})$ and excellent CVN absorbed impact-energy values. ${ }^{[18,21]}$ This steel is denoted NUCu100, where the number 100 stands for the yield strength of the steel in ksi.* For example, when NUCu-100 is

*The term NUCu stands for Northwestern University copper alloyed steel.

solutionized at $900{ }^{\circ} \mathrm{C}$ and aged at $524{ }^{\circ} \mathrm{C}$, the steel achieves a yield strength of $712 \mathrm{MPa}(103 \mathrm{ksi})$ at room temperature and a CVN absorbed impact energy of $64 \mathrm{~J}$ (47 ft-lbs) at $-40{ }^{\circ} \mathrm{C} \cdot{ }^{[18]}$ The strength of this steel is derived primarily from bcc $\mathrm{Cu}$ precipitates, although there is possibly a small contribution from niobiumcarbide $(\mathrm{NbC})$ precipitates at long aging times that delays overaging. ${ }^{[21-23]}$

Investigation, by atom-probe tomography (APT) ${ }^{[24-26]}$ of the bcc $\mathrm{Cu}$ precipitates in a NUCu-100 steel specimen solutionized for 30 minutes at $1100{ }^{\circ} \mathrm{C}$ and directly aged for 100 minutes at $490{ }^{\circ} \mathrm{C}$ demonstrated the existence of chemically complex $\mathrm{Cu}$-rich precipitates containing $\mathrm{Fe}$, $\mathrm{Ni}, \mathrm{Mn}$, and $\mathrm{Al} .{ }^{[27,28]}$ The precipitate $/ \alpha-\mathrm{Fe}$ matrix 
heterophase interfaces are enriched in $\mathrm{Ni}$ and $\mathrm{Mn}$ forming a spherical shell-like structure, whereas the Al enhancement is found toward the inner region of the $\mathrm{Cu}$ precipitates.

The focus of the present study is investigation of a ferritic multicomponent $\mathrm{Fe}-\mathrm{Cu}$-based steel with a yield strength of $965 \mathrm{MPa}$ (140 ksi), which also possesses an elongation-to-failure greater than 15 pct, a CVN absorbed impact-energy as high as $74 \mathrm{~J}$ at $-40{ }^{\circ} \mathrm{C}$, potentially improved weldability (no brittle heat-affected zone), and better corrosion resistance. This HSLC steel is being studied in a program to develop an explosion resistant stee ${ }^{[29]}$ for the United States Navy.

We first discuss the results of preliminary research on an arc-melted heat demonstrating the viability of developing a HSLC steel with the described properties. We then discuss the results of a more comprehensive investigation on three 45.5-kg (100-1b) laboratory heats processed by ArcelorMittal Steel Global Research \& Development Laboratory. We show the effects on microstructure and mechanical properties of increasing the nominal $\mathrm{Ni}$ and $\mathrm{Al}$ concentrations from that found in $\mathrm{NUCu}-100$. The presence of the $\mathrm{Cu}-$ rich $^{[30]}$ precipitates is verified and characterized in detail using APT. Additionally, $\mathrm{NbC}$ and heterogeneously nucleated NiAl-type precipitates are present. The results of preliminary welding studies are discussed.

\section{PRELIMINARY RESEARCH}

Initial research was done on a 100-gram steel heat arcmelted in an argon atmosphere. Additional $\mathrm{Ni}$ and $\mathrm{Al}$ (>99.99 at. pet pure) were added to a piece of $525 \mathrm{MPa}$ (76 ksi) yield strength $\mathrm{NUCu}$ steel. Ni and Al have an additive effect on the precipitation strengthening, ${ }^{[31-33]}$ permitting the development of even stronger steels. The $\mathrm{Ni}$ and $\mathrm{Al}$ concentrations were selected based on prior experience. ${ }^{[34,35]}$ The composition of the arc-melted steel heat is given in Table I. The resulting 12.3-mm-diameter ingot was homogenized at $1150{ }^{\circ} \mathrm{C}$ for 72 hours and then cold swaged, without intermediate anneals, producing a 6-mm-diameter rod. This represents a 75 pct reduction in area, indicating that this steel possesses a significant capacity for cold working. The rods were solutionized at $1050{ }^{\circ} \mathrm{C}$, quenched into water at room temperature, and subsequently aged at $550{ }^{\circ} \mathrm{C}$ for
2 hours. Subsized tensile specimens with a 25.4-mm (1-in.) gage length were machined from the rod.

Tensile tests were performed at room temperature and at $-35^{\circ} \mathrm{C}$. At both temperatures, yield strengths of approximately $840 \mathrm{MPa}$ (122 ksi) and ultimate tensile strengths of approximately $945 \mathrm{MPa}$ (137 ksi) were obtained. The elongation-to-failure was approximately 30 pct at both testing temperatures. The fracture was completely ductile as characterized by the fracture surface. Additionally, a subscale CVN specimen tested at $-35^{\circ} \mathrm{C}$ only partially fractured and bent in the testing apparatus. As with the tensile specimens, the fracture was ductile.

\section{EXPERIMENTAL METHODS}

\section{A. Alloy Details}

Three 45.5-kg (100-lb) laboratory heats were produced for this research at ArcelorMittal Steel Global Research \& Development Laboratory by vacuum induction melting. The resulting slabs were prepared (top cropped, and the sides machined) and reheated to approximately $1150{ }^{\circ} \mathrm{C}$ and hot rolled into $12.3-\mathrm{mm}-$ (0.5-in.-) thick plates in several passes. The temperature of the final pass was approximately $900{ }^{\circ} \mathrm{C}$. The compositions of the three heats, determined by spectrographic analysis at ArcelorMittal Steel, are given in Table I. The heats are denoted NUCu-140-x, where 140 stands for the target yield strength in $\mathrm{ksi}$ and $x$ designates the heat number. ${ }^{* *}$ The $N$ content does not

\footnotetext{
**In earlier publications and conference proceedings, we denoted the same heats as NUCu-150- $x$ or AlNiCu-150- $x$. We make the change to $\mathrm{NUCu}-140-x$ to better relate the steel to similar $\mathrm{Cu}$ alloyed steels previously developed at Northwestern University.
}

exceed 0.001 wt pct, a result of the vacuum induction melting process. The nominal concentrations of $S$ and $P$ should be as small as possible. In the NUCu-140-2 heat, however, the $P$ concentration is $0.014 \mathrm{wt}$ pct, which is 2 to 4 times greater than in the other two heats. The plates were mechanically cut into rods $(12.3 \mathrm{~mm} \times 12.3 \mathrm{~mm} \times$ $250 \mathrm{~mm}$ ) and solutionized at $900{ }^{\circ} \mathrm{C}, 1000^{\circ} \mathrm{C}$, or $1100{ }^{\circ} \mathrm{C}$, followed by quenching into water at room temperature.

Table I. Compositions of NUCu-140-x Steels (Weight Percent and Atomic Percent)*

\begin{tabular}{lcccccccccc}
\hline & & $\mathrm{C}$ & $\mathrm{Mn}$ & $\mathrm{Si}$ & $\mathrm{Cu}$ & $\mathrm{Ni}$ & $\mathrm{Al}$ & $\mathrm{Nb}$ & $\mathrm{P}$ & $\mathrm{S}$ \\
\hline Arc-melted steel & wt pct & 0.04 & 0.47 & 0.47 & 1.36 & 2.78 & 0.66 & 0.07 & 0.007 & 0.001 \\
& at. pct & 0.19 & 0.48 & 0.94 & 1.19 & 2.64 & 1.37 & 0.042 & 0.013 & 0.002 \\
NUCu-140-1 & wt pct & 0.05 & 0.47 & 0.46 & 1.34 & 2.71 & 0.60 & 0.07 & 0.005 & 0.001 \\
& at. pct & 0.23 & 0.48 & 0.92 & 1.17 & 2.57 & 1.24 & 0.042 & 0.009 & 0.002 \\
NUCu-140-2 & wt pct & 0.04 & 0.48 & 0.48 & 1.37 & 2.86 & 0.69 & 0.07 & 0.014 & 0.004 \\
& at. pct & 0.19 & 0.49 & 0.96 & 1.20 & 2.71 & 1.43 & 0.042 & 0.025 & 0.007 \\
NUCu-140-3 & wt pct & 0.05 & 0.52 & 0.48 & 1.29 & 2.87 & 0.58 & 0.07 & 0.004 & 0.005 \\
& at. pct & 0.23 & 0.53 & 0.96 & 1.13 & 2.72 & 1.20 & 0.042 & 0.007 & 0.009 \\
\hline
\end{tabular}

*Nitrogen content does not exceed 0.001 wt pct. 
The tensile specimens are ASTM standard specimens (ASTM E 8 - 04) with a gage length of 25.4-mm (1-in.) and a diameter of 6-mm (0.25-in.). The CVN specimens are also ASTM standard size specimens (ASTM E 23 02a). The specimens and additional material $(12.3 \mathrm{~mm} \times$ $12.3 \mathrm{~mm} \times 25 \mathrm{~mm}$ blocks) for hardness testing and APT were solutionized at $900^{\circ} \mathrm{C}$ and aged either at $500{ }^{\circ} \mathrm{C}$ or $550{ }^{\circ} \mathrm{C}$ and then quenched into water at room temperature precluding extra precipitation. The hardness and APT specimens were aged from 1 to 100 hours, whereas the tensile and CVN specimens were aged either for 6 hours at $500{ }^{\circ} \mathrm{C}$ or 2 hours at $550{ }^{\circ} \mathrm{C}$.

\section{B. Optical Microscopy}

Sections of the solutionized and water-quenched specimens perpendicular to the rolling direction were cold mounted and polished to a final surface finish of $1 \mu \mathrm{m}$ using standard procedures. The mounted specimens were etched for approximately 10 to 15 seconds with a 2 vol pet Nital solution allowing observation of the microstructures.

\section{Mechanical Properties}

Hardness testing was performed using a Wilson Rockwell hardness tester using the standard Rockwell diamond indenter and a 150-kg testing load (Rockwell C scale). Tensile testing was performed on a Sintech screwdriven testing machine in accordance with ASTM standards (ASTM E 8 - 04), with a 20-kilopound (kip) load cell under displacement control at a strain rate of $0.04 \mathrm{~s}^{-1}$. The specimen strain was measured using a 1 -in. extensometer. The CVN tests were performed using a Tinius Olsen impact-testing machine in accordance with ASTM standards (ASTM E 23 - 02a).

\section{Welding Studies}

Welding tests were performed on the NUCu-140-1 steel heat. Welding rods for the $965 \mathrm{MPa}$ yield strength level are not commercially available; therefore, a 10mm-diameter section of NUCu-140-1 steel was cold swaged to a $2.5-\mathrm{mm}$ diameter for use as a welding rod. A 12.3-mm-thick plate of NUCu-140-1 was solutionized at $900{ }^{\circ} \mathrm{C}$, water quenched to room temperature, and then aged for 2 hours at $550{ }^{\circ} \mathrm{C}$. A bead of the welding rod was melted on the aged plate using argon-shielded metal arc welding; the heat input was $3.6 \mathrm{~kJ} \mathrm{~mm}^{-1}$ and the travel speed was $2.5 \mathrm{~mm} \mathrm{~s}^{-1}$.

Specimens were mechanically cut from the welded plate, cold mounted, and polished, using standard procedures, to a final surface finish of $1 \mu \mathrm{m}$ for optical microscopy and hardness testing. Hardness testing was performed in accordance with ASTM standards (ASTM E 384 - 99) using a Buehler Micromet II microhardness tester with a Vickers microhardness indenter, a load of $200 \mathrm{~g}$, and a testing time of 10 seconds. The results were reported in GPa. Vickers microhardness (HVN) testing was performed to discern the changes in hardness within the weld, fusion zone (FZ), and heat-affected zone
(HAZ) on a shorter length scale than accessible with standard Rockwell hardness C (HRC) testing. For optical microscopy, the specimens were etched for approximately 10 to 15 seconds with a 2 vol pet Nital solution.

\section{E. Atom-Probe Tomography}

Atom-probe tomography tip blanks $(0.3 \mathrm{~mm} \times 0.3$ $\mathrm{mm} \times 25 \mathrm{~mm}$ ) were mechanically cut from the aged blocks. The APT tip blanks were electropolished using standard procedures. ${ }^{[24,36]}$ Initial polishing was performed with a solution of $10 \mathrm{vol}$ pet perchloric acid in acetic acid at 8 to $20 \mathrm{Vdc}$ at room temperature. This was followed by final electropolishing using a solution of 2 vol pet perchloric acid in butoxyethanol at 8 to $15 \mathrm{Vdc}$, producing a tip with a radius $<50 \mathrm{~nm}$. LEAP and conventional three-dimensional atom-probe (3DAP) tomography ${ }^{[24-26]}$ were performed at a specimen temperature of $50 \mathrm{~K}$ and a residual pressure of $<1 \times 10^{-8} \mathrm{~Pa}$. The pulse repetition rate was $2 \times 10^{5} \mathrm{~Hz}$ and the pulseto-standing-dc voltage ratio (pulse fraction) was 15 to 20 pct. Visualization and quantitative evaluation of datasets were performed with the Imago Visualization and Analysis Software (IVAS $S^{\dagger}$ ) and with ADAM 1.5, a

\footnotetext{
${ }^{\dagger}$ IVAS is a trademark of Imago Scientific Instruments, Madison, WI
}

custom software application developed at Northwestern University. ${ }^{[37]}$ Compositional analyses of the precipitates, their heterophase interfaces, and matrix were performed with the proximity histogram method (proxigram for short), giving compositional profiles with respect to distance from an isoconcentration surface. ${ }^{[37-39]}$ The $\mathrm{Cu}$-rich precipitates were delineated by a 5 at. pct $\mathrm{Cu}$ isoconcentration surface. The parameters chosen for obtaining a noise-free reference isoconcentration surface are a voxel size of 0.8 to $1.0 \mathrm{~nm}$, a delocalization distance of $2.0 \mathrm{~nm}$, and a confidence sigma parameter $\leq 1$. Neither the reference isoconcentration surface nor the proxigrams varied significantly when these parameters were changed by up to $50 \mathrm{pct}$, indicating a numerically stable evaluation procedure and representative results.

The volume equivalent radius, ${ }^{[40]} R$, of a precipitate is given by

$$
R=\left(\frac{3}{4 \pi} \frac{n \Omega}{\eta}\right)^{\frac{1}{3}}
$$

where $n$ is the number of atoms detected within a delineated precipitate, the atomic volume, $\Omega$, is $1.178 \times 10^{-2} \mathrm{~nm}^{3}$ for bcc Fe, and the overall detection efficiency, $\eta$, of the multichannel detector plate is estimated to be 0.5 . The value of $n$ belonging to a precipitate is determined from the envelope method ${ }^{[24,41]}$ based on a maximum separation distance of $0.5 \mathrm{~nm}$, a minimum precipitate size of $20 \mathrm{Cu}$ atoms, and a grid spacing of $0.15 \mathrm{~nm}$. 


\section{RESULTS}

\section{A. Optical Microscopy}

Figures 1(a) and 1(b) display the microstructure of $\mathrm{NUCu}-140-1$ after quenching from $900{ }^{\circ} \mathrm{C}$ and $1100{ }^{\circ} \mathrm{C}$, respectively. After quenching from $900{ }^{\circ} \mathrm{C}$, the microstructure consists of equiaxed grains and a smaller volume fraction of elongated, acicular-like grains. The average ferrite grain size, determined by the ASTM intercept method (ASTM E $112-96$ ), is $7 \mu \mathrm{m}$. Increasing the solutionizing temperature to $1100{ }^{\circ} \mathrm{C}$ increases significantly the average ferrite grain size to $42 \mu \mathrm{m}$ and the grains are blocklike in shape with some containing distinct lathlike features. Solutionizing at $1000{ }^{\circ} \mathrm{C}$ gives an intermediate microstructure with a grain size of $24 \mu \mathrm{m}$. The ferrite grain size is controlled by temperature, time at temperature, and the presence of $\mathrm{NbC}$ in the austenite during solutionizing. The solubility of $\mathrm{NbC}$ in austenite increases as the temperature increases. For example, with low $\mathrm{C}$ content, the solubility of $\mathrm{Nb}$ in austenite increases from $3 \times 10^{-3}$ wt pct at $900{ }^{\circ} \mathrm{C}$ to $4 \times 10^{-2}$ wt pet at $1100^{\circ} \mathrm{C}$. ${ }^{[1-23]}$

The microstructure of $\mathrm{NUCu}-140-3$ is similar to $\mathrm{NUCu}-140-1$, but with a slightly larger grain size of $8.6 \mu \mathrm{m}$ when solutionized at $900^{\circ} \mathrm{C}$. The grains of NUCu-140-2, when solutionized at $900{ }^{\circ} \mathrm{C}$, are mixture of elongated acicular grains and blocklike grains, similar

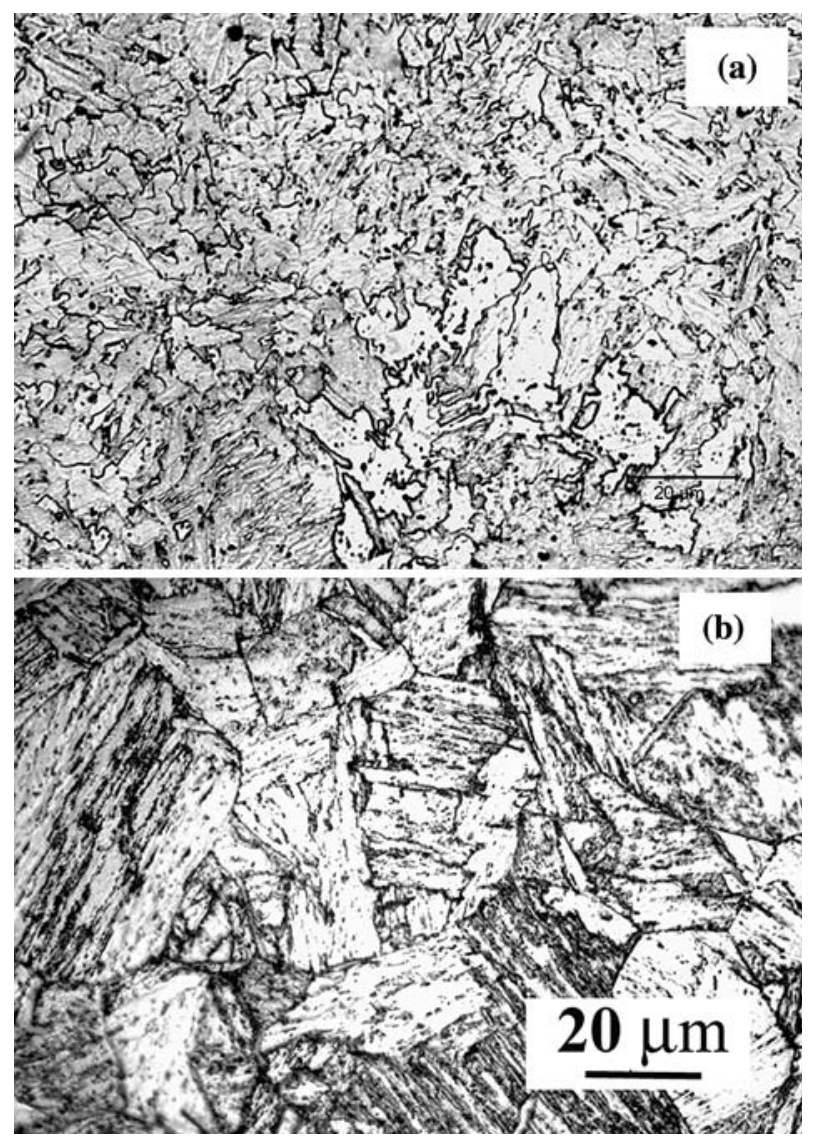

Fig. 1-Microstructure of NUCu-140-1 steel solutionized at (a) $900{ }^{\circ} \mathrm{C}$ or $(b) 1100{ }^{\circ} \mathrm{C}$ and quenched into room-temperature water. to that observed when NUCu-140-1 is solutionized at $1100{ }^{\circ} \mathrm{C}$. The grain size is $10.3 \mu \mathrm{m}$.

\section{B. Mechanical Properties}

Figure 2 shows hardness vs aging time for $\mathrm{NUCu}-$ 140-1 as a function of solutionizing and aging temperatures. As depicted by the hardness curves the steel ages faster at an aging temperature of $550{ }^{\circ} \mathrm{C}$ than at $500{ }^{\circ} \mathrm{C}$. Also, higher solutionizing temperatures result in an increased hardness. The measured maximum hardness at $500{ }^{\circ} \mathrm{C}$ (Figure 2(a)) aging is higher than that at $550{ }^{\circ} \mathrm{C}$ (Figure 2(b)). Two hardness peaks are observed at both aging temperatures. When aged at $500{ }^{\circ} \mathrm{C}$, the first hardness peak occurs at 5 to 6 hours (Figure 2(a)), whereas the second peak occurs at approximately 12 to 24 hours (Figures 2(a) and 2(c)). At 100 hours, the hardness decreases to 37 from $38.5 \mathrm{HRC}$, indicating that the steel is overaged (Figure 2(c)). When aged at $550{ }^{\circ} \mathrm{C}$, however, the first hardness peak occurs at approximately 2 hours, whereas the second peak occurs between 5 and 6 hours (Figure 2(b)). The hardness value decreases at 7 hours indicating overaging (Figure 2(c)).

Figure 3 shows the engineering stress $v s$ engineering strain curves for NUCu-140-1 as a function of solution-

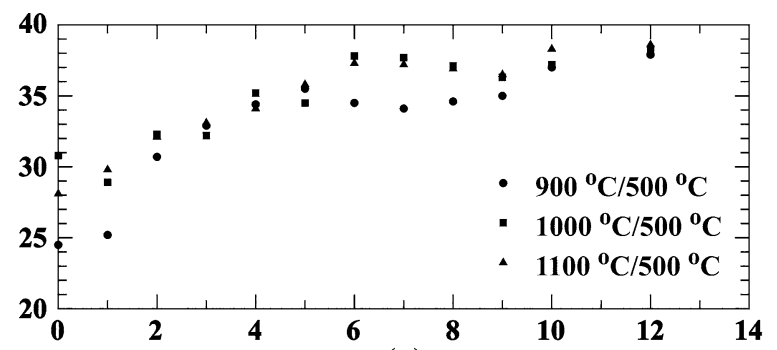

(a)

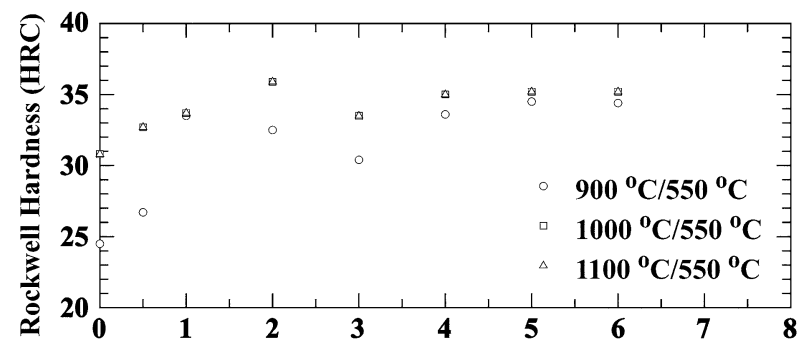

(b)

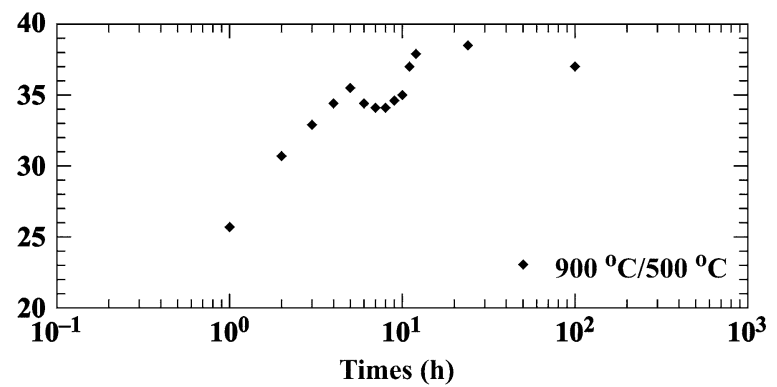

(c)

Fig. 2-Rockwell hardness C of NUCu-140-1 steel vs aging time, after solutionizing at $900{ }^{\circ} \mathrm{C}$, when aged to $(a) 12 \mathrm{~h}$ at $500{ }^{\circ} \mathrm{C}$, to $(b)$ $6 \mathrm{~h}$ at $550{ }^{\circ} \mathrm{C}$, and to $(c) 100 \mathrm{~h}$ at $500{ }^{\circ} \mathrm{C}$. 


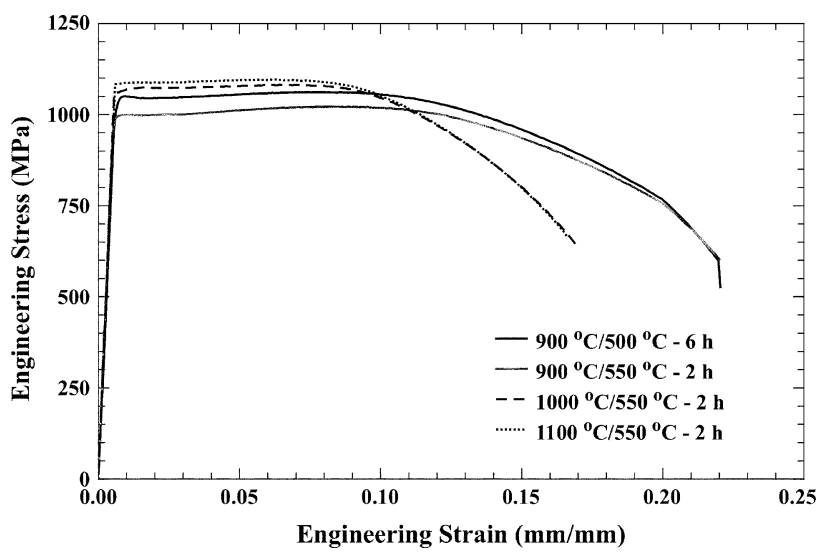

Fig. 3-Engineering stress $v s$ engineering strain curves for $\mathrm{NUCu}-$ 140-1 steel. The specimens are solutionized at $900{ }^{\circ} \mathrm{C}, 1000{ }^{\circ} \mathrm{C}$, or $1100{ }^{\circ} \mathrm{C}$ and then aged for either 2 or $6 \mathrm{~h}$ at $500{ }^{\circ} \mathrm{C}$ or $550{ }^{\circ} \mathrm{C}$. The strain rate is $0.04 \mathrm{~s}^{-1}$.

izing and aging temperature. Increasing the solutionizing temperature results in greater yield and ultimate tensile strength values. The 0.2 pct offset yield strength of the steel after quenching from $900{ }^{\circ} \mathrm{C}$ and aging for 2 hours at $550{ }^{\circ} \mathrm{C}$ is $973 \mathrm{MPa}(141 \mathrm{ksi})$. The yield strength increases by more than 10 pet to $1096 \mathrm{MPa}$ (159 ksi) when the steel is quenched from $1100{ }^{\circ} \mathrm{C}$ and aged for 2 hours at $550{ }^{\circ} \mathrm{C}$. This increase in yield strength, however, is accompanied by a decrease in elongation-to-failure from approximately 22 pct when solutionized at $900{ }^{\circ} \mathrm{C}$ to approximately $17 \mathrm{pct}$ when the steel is solutionized at either $1000{ }^{\circ} \mathrm{C}$ or $1100{ }^{\circ} \mathrm{C}$. $\mathrm{NUCu}-140-1$ aged for 6 hours at $500{ }^{\circ} \mathrm{C}$, however, has given a larger value of yield strength, $1001 \mathrm{MPa}$ (145 ksi) than when aged at $550{ }^{\circ} \mathrm{C}$ for 2 hours. The tensile fracture surfaces of all the specimens exhibit a classic cup-and-cone type surface with dimpling indicating ductile failure.

Table II summarizes the tensile properties of the three steel heats when solutionized at $900{ }^{\circ} \mathrm{C}$ and aged for either 2 hours at $550{ }^{\circ} \mathrm{C}$ or 6 hours at $500{ }^{\circ} \mathrm{C}$. A $900{ }^{\circ} \mathrm{C}$ solutionizing temperature was selected as this gives the most clearly ferritic microstructure (Figure 1) and the largest value for the elongation-to-failure, with only a minimal loss of yield strength when compared with solutionizing at $1000{ }^{\circ} \mathrm{C}$ or $1100{ }^{\circ} \mathrm{C}$ (Figure 3). The aging times were selected for near-peak hardness values at the given aging temperature (Figure 2).
When aged at $550^{\circ} \mathrm{C}, \mathrm{NUCu}-140-2$ has the largest yield strength, $1049 \mathrm{MPa}$ (152 ksi). The elongation-tofailure value is 20 pct, which is lower than the two other heats. NUCu-140-3 is the least strong heat with a yield strength of $849 \mathrm{MPa}$ (123 ksi). Table III displays the CVN absorbed impact-energy values for the three heats when tested between $25^{\circ} \mathrm{C}$ and $-62{ }^{\circ} \mathrm{C}$. NUCu-140-1 and $\mathrm{NUCu}-140-3$ have similar values of $\mathrm{CVN}$ absorbed impact-energy and, therefore, possess good cryogenic impact toughness. NUCu-140-2, however, is more brittle at room temperature. Figures 4(a) and 4(b) display the fracture surfaces of $\mathrm{NUCu}-140-1$ and NUCu-140-2 Charpy specimens tested at room temperature. The NUCu-140-1 specimen exhibits significant plastic deformation with shear lips seen on the edges and a granular center region. The NUCu-140-2 specimen shown exhibits little if any plastic deformation and the failure surface is cleavagelike, as determined by scanning electron microscopy (SEM).

When aged at $500{ }^{\circ} \mathrm{C}, \mathrm{NUCu}-140-1$ exhibits the largest value of the yield strength, $1001 \mathrm{MPa}(145 \mathrm{ksi})$. NUCu-140-3 is somewhat weaker with a yield strength of $911 \mathrm{MPa}(132 \mathrm{ksi})$. Both heats have similar values of elongation-to-failure, 22 pct. The CVN absorbed impact energies are significantly lower when the steel is aged at $500{ }^{\circ} \mathrm{C}$. For example, when NUCu-140-1 is aged at $550{ }^{\circ} \mathrm{C}$ for 2 hours the absorbed impact-energy at room temperature is $208 \mathrm{~J}$ (153 ft-lbs), but when aged at $500{ }^{\circ} \mathrm{C}$ for 6 hours, the absorbed impact-energy at room temperature is only $82 \mathrm{~J}$ (60 ft-lbs). A comparable difference exists when the heat is tested at $-23{ }^{\circ} \mathrm{C}$. The $\mathrm{NUCu}-140-3$ heat also demonstrates a similar variation when aged at $500{ }^{\circ} \mathrm{C}$ and $550{ }^{\circ} \mathrm{C}$. We did not test NUCu-140-2 aged at $500{ }^{\circ} \mathrm{C}$, because the CVN tests indicated that the heat is brittle under impact loading.

Table III. Charpy V-Notch Absorbed Impact Energy for Steels Solutionized at $900{ }^{\circ} \mathrm{C}$ and Aged for 2 h at $550^{\circ} \mathrm{C}$

\begin{tabular}{lccc}
\hline & \multicolumn{3}{c}{ Charpy Absorbed Impact Energy, J } \\
\cline { 2 - 4 } Temperature, ${ }^{\circ} \mathrm{C}$ & NUCu-140-1 & NUCu-140-2 & NUCu-140-3 \\
\hline 25 & 208 & 71 & 212 \\
-12 & 79 & - & - \\
-23 & 79 & 19 & 52 \\
-40 & 66 & - & 74 \\
-62 & 25 & - & - \\
\hline
\end{tabular}

Table II. Tensile Properties of NUCu-140-1, NUCu-140-2, and NUCu-140-3 Steels Solutionized at $900{ }^{\circ} \mathrm{C}$ and Aged at Either $550{ }^{\circ} \mathrm{C}$ or $500{ }^{\circ} \mathrm{C}$

\begin{tabular}{|c|c|c|c|c|c|c|}
\hline & \multicolumn{3}{|c|}{ Aged $2 \mathrm{~h}$ at $550^{\circ} \mathrm{C}$} & \multicolumn{3}{|c|}{ Aged $6 \mathrm{~h}$ at $500^{\circ} \mathrm{C}$} \\
\hline & $\begin{array}{l}\text { Yield } \\
\text { Stress } \\
(\mathrm{MPa})\end{array}$ & $\begin{array}{l}\text { UTS } \\
\text { (MPa) }\end{array}$ & $\begin{array}{l}\text { Elongation-to- } \\
\text { Failure (Pct) }\end{array}$ & $\begin{array}{l}\text { Yield } \\
\text { Stress } \\
\text { (MPa) }\end{array}$ & UTS (MPa) & $\begin{array}{l}\text { Elongation-to- } \\
\text { Failure (Pct) }\end{array}$ \\
\hline NUCu-140-1 & 973 & 994 & 22 & 1001 & 1042 & 22 \\
\hline NUCu-140-2 & 1049 & 1049 & 20 & - & - & - \\
\hline NUCu-140-3 & 849 & 890 & 23 & 911 & 952 & 22 \\
\hline
\end{tabular}



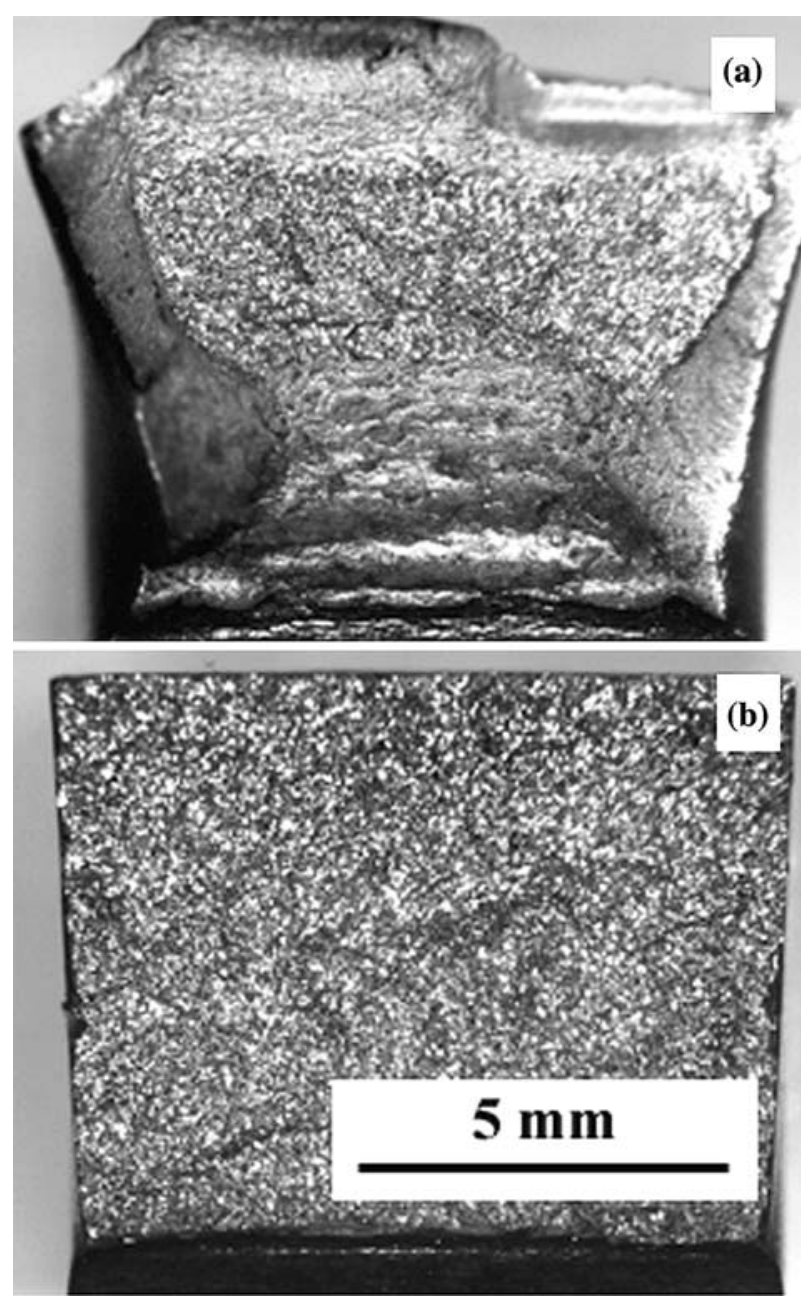

Fig. 4-The Charpy V-notch specimen fracture surfaces as observed by optical microscopy, for testing at room temperature: (a) $\mathrm{NUCu}-$ 140-1 and (b) NUCu-140-2.

\section{Welding Studies}

The microhardness profile and optical micrographs of the weld, FZ, HAZ, and base plate are presented in Figure 5. The Vickers microhardness value of the base plate (Figure 5(d)) is $3.2 \mathrm{GPa}$ prior to welding. The microhardness in the HAZ (Figure 5(c)) is reduced to $2.0 \mathrm{GPa}$, whereas the FZ (Figure 5(b)) and weld (Figure 5(a)) have a microhardness value of approximately $2.7 \mathrm{GPa}$. The micrographs indicate that the grain size is much larger in the weld and FZ than in the HAZ or base metal. The grain size in the HAZ is equal to $3.2 \mu \mathrm{m}$, whereas the grain sizes in the FZ and weld are 15 and $34 \mu \mathrm{m}$, respectively. The grains within the FZ are either acicular in appearance or possess a blocklike appearance, whereas the grains within the weld have predominantly large blocklike shapes The grains in the HAZ are similar in appearance to the base metal, which consists of equiaxed grains with a smaller volume fraction of elongated grains.

\section{Atom-Probe Tomography}

Figure 6(a) displays the atom-by-atom reconstruction of a $44 \times 44 \times 78 \mathrm{~nm}^{3}$ volume of NUCu-140-1 quenched from $900{ }^{\circ} \mathrm{C}$ and aged at $500{ }^{\circ} \mathrm{C}$ for 24 hours. The $\mathrm{Cu}$ atoms, shown as red dots, have aggregated to form $\mathrm{Cu}$-rich precipitates, a few of which are labeled by arrows with the letter " $A$ " in the figure. The mean radius, $\langle R\rangle$, of these precipitates, after 24 hours of aging, is $1.5 \pm 0.1 \mathrm{~nm}$ and their number density is $N_{V}=(1.2 \pm 0.1) \times 10^{24} \mathrm{~m}^{-3}$. Figure 7 displays the evolution of the quantity $\langle R\rangle$ with time when the steel is aged at $500{ }^{\circ} \mathrm{C}$. The aging times investigated coincide with underaged, near peak hardness, and overaged conditions. The value of $\langle R\rangle$ increases from $0.9 \mathrm{~nm}$ at 3 hours to $1.8 \mathrm{~nm}$ at 100 hours, with the quantity $N_{V}$ concomitantly decreasing from $(3.3 \pm 0.7) \times 10^{24}$ to $(6.1 \pm 1.5) \times 10^{23} \mathrm{~m}^{-3}$. The temporal evolution of the particle size distributions (PSDs) for all three aging times is discussed elsewhere in detail. ${ }^{[30]}$ The compositional evolution of the $\mathrm{Cu}$-rich precipitates is also presented in Reference 30, and the results are summarized briefly herein. Most importantly, the precipitates are $\mathrm{Cu}$-rich containing significant concentrations of $\mathrm{Fe}$, $\mathrm{Ni}, \mathrm{Al}$, and $\mathrm{Mn}$. The precipitate cores contain only about 50 at. pet $\mathrm{Cu}$ after 3 hours of aging at $500{ }^{\circ} \mathrm{C}$, and the core $\mathrm{Cu}$ concentration does not increase further with aging up to 100 hours. The precipitate contains a substantial amount of Fe. The precipitates are enriched to about 10 at. pet Ni, 15 at. pct Al, and 1.5 at. pct $\mathrm{Mn}$ after 24 hours of aging. At this time, a spherical shell surrounds each precipitate with increasing $\mathrm{Ni}, \mathrm{Al}$, and Mn concentrations developing at the precipitate $/ \alpha-\mathrm{Fe}$ matrix heterophase interfaces of the $\mathrm{Cu}$-rich precipitates. Additionally, the gradient of the copper concentration profiles across the interfaces become sharper. After 100 hours of aging, the surrounding spherical shell contains 17 at. pet $\mathrm{Ni}, 15$ at. pet $\mathrm{Al}$, and 2.6 at. pet $\mathrm{Mn}$, and these elements are concurrently depleted in the core of the $\mathrm{Cu}$-rich precipitates. The enrichment of $\mathrm{Ni}, \mathrm{Al}$, and $\mathrm{Mn}$ at the precipitate $/ \alpha-\mathrm{Fe}$ matrix heterophase interfaces occurs subsequent to the formation of the $\mathrm{Cu}$-rich precipitates, as discussed in detail elsewhere. ${ }^{[30]}$

In addition to the $\mathrm{Cu}$-rich precipitates, a small $\mathrm{NbC}$ precipitate is observed, as shown in Figure 6(b), the more highly magnified area with the label "B" in Figure 6(a). This NbC precipitate shown is approximately $3.5 \mathrm{~nm}$ in radius and $N_{V}$ is estimated to be in the range $10^{21}$ to $10^{22} \mathrm{~m}^{-3}$, which is two orders of magnitude less than the $N_{V}$ value for the $\mathrm{Cu}$-rich precipitates.

Figure 8 displays a three-dimensional reconstruction of a sample region intersecting a grain boundary (GB), obtained from the NUCu-140 arc-melted heat after 100 hours of aging at $500{ }^{\circ} \mathrm{C}$. The location of the $\mathrm{GB}$ is indicated by the dashed lines with the label "GB" in Figure 8 and is unambiguously identified by the discontinuity in a set of resolved $\{110\}$ lattice planes visible in a different projection of the three-dimensional dataset. This GB is enriched in carbon with peak concentrations of up to approximately 3 at. pct locally, and additionally shows segregation of $B$ and $P$, but no significant enrichment in $S$, as discussed elsewhere. ${ }^{[30]}$ At the positions with label "A" are Cu-rich precipitates analogous to the $\mathrm{Cu}$-rich precipitates visible in Figure 6. At label "B" in Figure 8 is a precipitate about $3 \mathrm{~nm}$ in radius that is highly enriched in $\mathrm{Ni}$ and $\mathrm{Al}$. A proxigram 


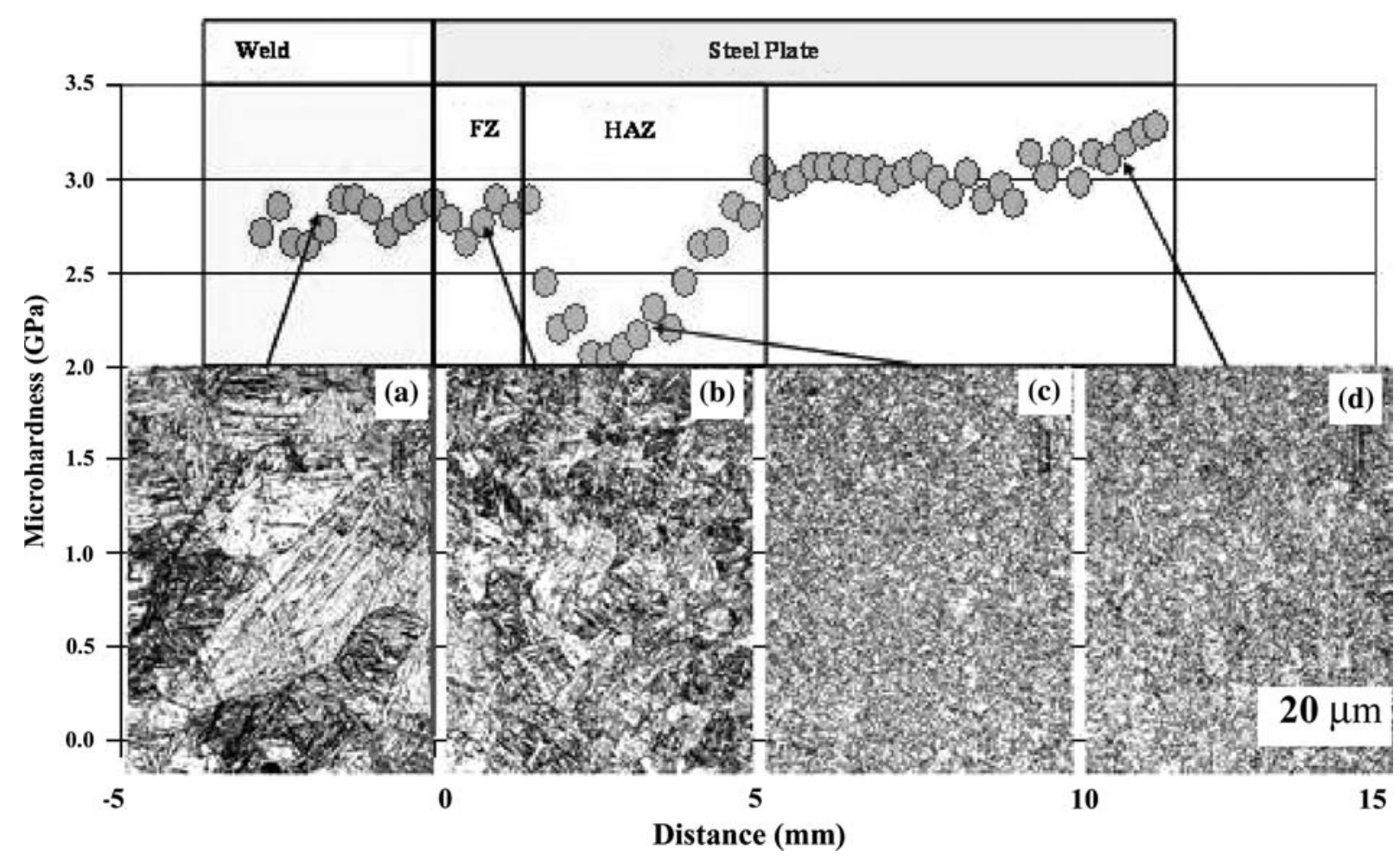

Fig. 5-Vickers microhardness profile and microstructures of the welded NUCu-140-1 steel plate. The microstructures are $(a)$ weld, $(b)$ fusion zone, $(c)$ heat-affected zone, and $(d)$ plate.

concentration profile analysis reveals that the composition of this precipitate is $36 \pm 2 \mathrm{Ni}-40 \pm 2 \mathrm{Al}-$ $11 \pm 2 \mathrm{Fe}-7 \pm 1 \mathrm{Mn}-4 \pm 1 \mathrm{Cu}-0.8 \pm 0.4 \mathrm{Si}$ (at. pct), whereas $\mathrm{C}$ and $\mathrm{Nb}$ were not detected.

\section{DISCUSSION}

\section{A. Microstructure and Mechanical Properties}

The multiple hardening peaks seen in Figure 2 are probably related to the temporal evolution of the complex $\mathrm{Cu}$-rich precipitates.

The smaller CVN absorbed impact-energy values for $\mathrm{NUCu}-140-2$ require discussion. Elevated concentration of $P$ in this heat may play a role because segregation of $P$ to GBs is known to result in embrittlement of steels. ${ }^{[42-44]}$ Segregation of $P$, in addition to $C, B$, and $S$, is observed at a GB in a steel designated NUCu-170, which was made at the same time as $\mathrm{NUCu}-140-2 .^{[30]}$ However, the small differences in the $P$ contents in the three heats (Table I) seem to be too small to give such a drastic reduction in Charpy value. Also, the cleavage nature of the fracture surface indicates that the fracture is mainly planar in nature and not intergranular. The grains of $\mathrm{NUCu}-140-2$, when solutionized at $900{ }^{\circ} \mathrm{C}$, are larger $(10.3 \mu \mathrm{m}$ compared with $\mathrm{NUCu}-140-1$ and NUCu-140-3, 7.0, and $8.6 \mu \mathrm{m}$, respectively). Also, the grains in NUCu-140-2 are more acicular. The origin of the impact loading embrittlement in NUCu-140-2 requires further investigation.
The smaller yield strength value of $\mathrm{NUCu}-140-3$, when compared with NUCu-140-1, is primarily attributed to the larger grain size, but the smaller $\mathrm{Cu}$ concentration, 1.29 wt pct, compared with 1.34 wt pct, plays a small role. The Hall-Petch relationship, ${ }^{[45,46]}$ $\sigma_{Y S} \propto d^{-1 / 2}$, where $d$ is the grain diameter and $\sigma_{Y S}$ correlates with the reduced yield strength.

We attribute the change in yield strength and elongation-to-failure when varying the solutionizing temperature to the increase in volume fraction of large grains containing lathlike features, most likely indicating an increasing amount of low-carbon concentration martensite (Figure 1). The observed change in microstructure is related to the dissolution of $\mathrm{NbC}$ precipitates at the two higher solutionizing temperatures. Niobium-carbide precipitates pin the austenite GBs inhibiting grain growth during solutionizing. ${ }^{[4]}$ At higher solutionizing temperatures, the $\mathrm{NbC}$ precipitates dissolve, leading to larger austenitic grain diameters, which increase the hardenability. Aging at $500{ }^{\circ} \mathrm{C}$ gives a larger value of yield strength than aging at $550^{\circ} \mathrm{C}$. This is attributed to a smaller solid solubility of $\mathrm{Cu}$ at the lower temperature.

We attribute the relatively high CVN absorbed impact energies measured at temperatures below $0{ }^{\circ} \mathrm{C}$ to a possible reduction of the local Peierls stress in the matrix. Small, misfitting precipitates may locally decrease the Peierls stress and reduce the rate of increase in yield strength on cooling ${ }^{[48,49]}$ possibly resulting in an improvement to the CVN absorbed impact-energy values at low temperatures. 


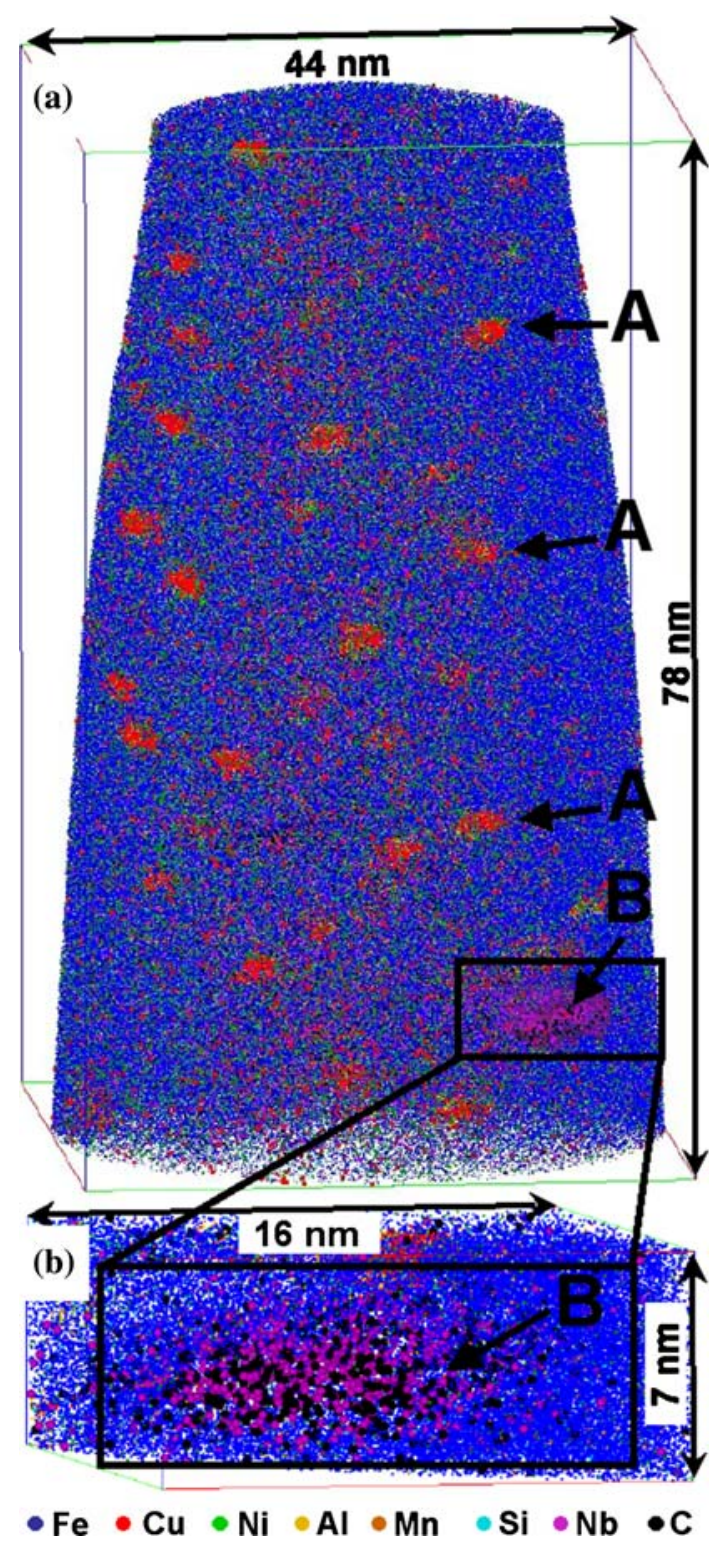

Fig. 6-Three-dimensional atom-by-atom LEAP tomographic reconstruction of NUCu-140-1 steel after quenching from $900{ }^{\circ} \mathrm{C}$ and aging at $500{ }^{\circ} \mathrm{C}$ for $24 \mathrm{~h}$. Copper atoms are shown as red dots; see color legend at the bottom. Nanometer-sized $\mathrm{Cu}$-rich precipitates have formed, see arrows with label "A" in $(a)$, with an average radius of $1.5 \pm 0.1 \mathrm{~nm}$, at a number density of $N_{V}=(1.2 \pm 0.1) \times$ $10^{24} \mathrm{~m}^{-3}$. Additionally, $\mathrm{NbC}$ precipitates are detected at a number density of approximately $10^{21}$ to $10^{22} \mathrm{~m}^{-3}$; see magnified area " $\mathrm{B}$ " in (b). The dimensions of the reconstructed volume in (a) are $44 \mathrm{~nm} \times$ $44 \mathrm{~nm} \times 78 \mathrm{~nm}$. Only 50 pct of the $\mathrm{Fe}$ atoms (blue color) are shown for clarity.

\section{B. Welding}

The preliminary welding experiment indicates that a high-strength welding filler metal could be developed on the basis of this steel. The reduction in hardness values within the HAZ is most likely a consequence of the growth and coarsening of the $\mathrm{Cu}$-rich precipitates since the matrix remains fine-grained ferrite as in the base plate. We note, however, that a brittle martensitic HAZ is not formed.

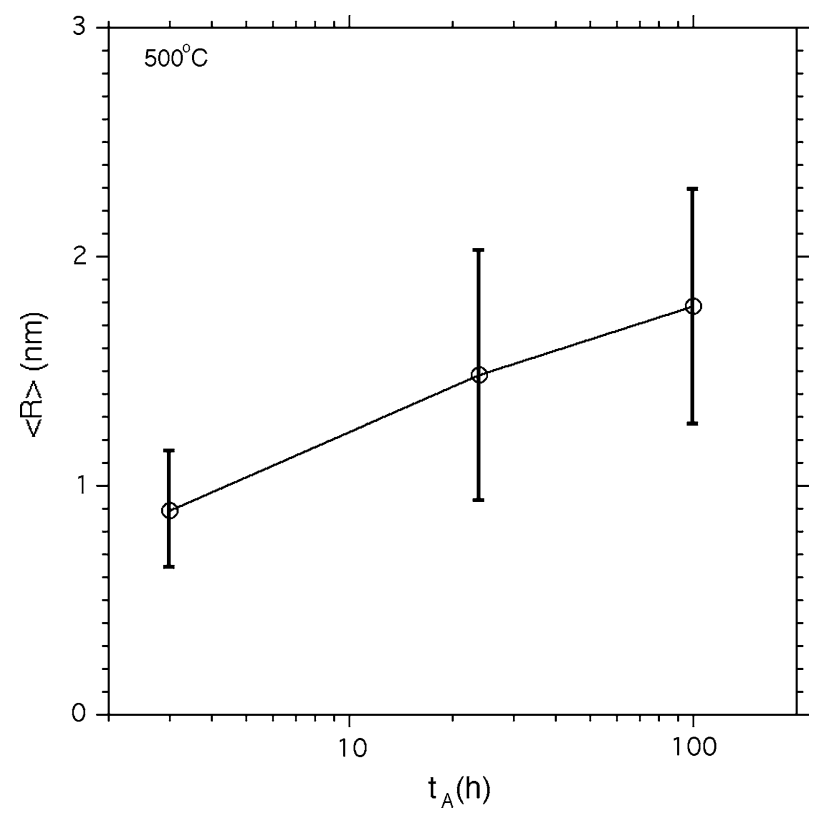

Fig. 7-Temporal evolution of the mean precipitate radius, $\langle R\rangle$, of the $\mathrm{Cu}$-rich precipitates in NUCu-140-1 at $500{ }^{\circ} \mathrm{C}$. The quantity $\langle R\rangle$ is given for 3,24 , and $100 \mathrm{~h}$ aging and was determined from PSDs containing 208,94 , and 42 precipitates, respectively. ${ }^{[30]}$ The quantity $\langle R\rangle$ increases from $0.9 \mathrm{~nm}$ after $3 \mathrm{~h}$ aging to $1.8 \mathrm{~nm}$ after $100 \mathrm{~h}$ aging.

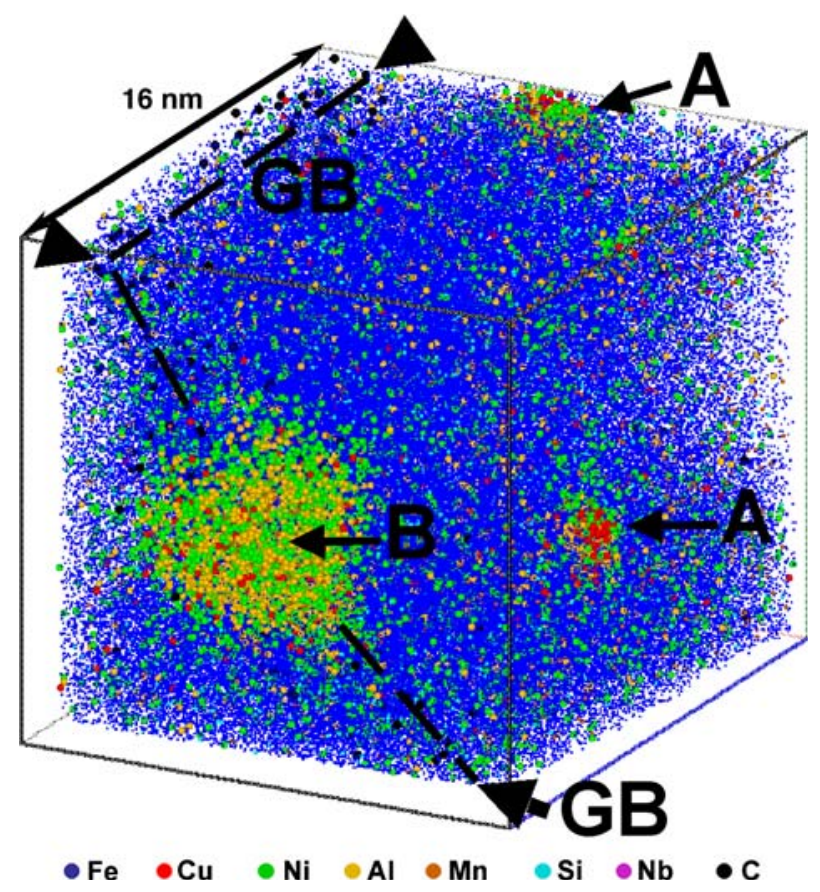

Fig. 8-Three-dimensional atom-by-atom conventional 3DAP tomographic reconstruction of NUCu-140-laboratory heat after quenching from $900{ }^{\circ} \mathrm{C}$ and aging $100 \mathrm{~h}$ at $500{ }^{\circ} \mathrm{C}$. In addition to small nanometer-sized $\mathrm{Cu}$-rich precipitates, label "A," a grain boundary that is enriched in $C, B$, and $P$ runs diagonally through the reconstruction volume. A larger precipitate highly enriched in $\mathrm{Ni}$ and $\mathrm{Al}$, label "B," has formed at the grain boundary. The dimensions of the reconstructed volume are $16 \mathrm{~nm} \times 16 \mathrm{~nm} \times 19 \mathrm{~nm}$. 


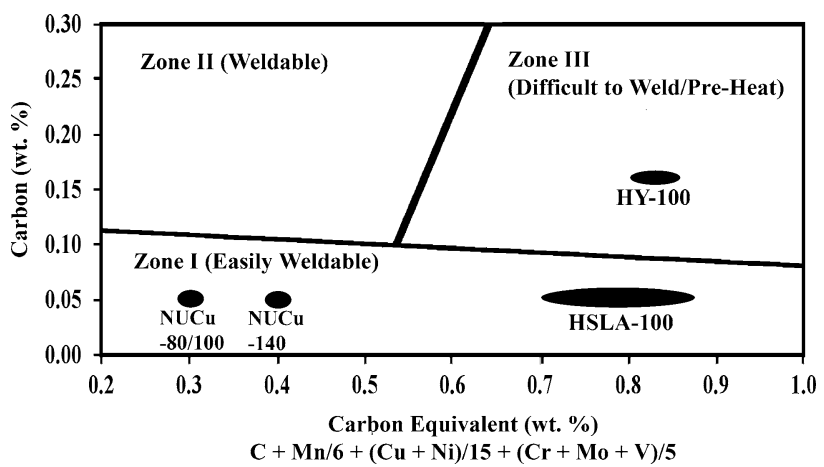

Fig. 9- Carbon equivalent diagram (Graville diagram) comparing the weldability of the NUCu series of steels with HSLA-100 and HY-100 steels. The comparatively low carbon equivalent of $\mathrm{NUCu}-$ 140- $x, 0.4 \mathrm{wt}$ pct, indicates that the steels are weldable without concern for a brittle HAZ.

The carbon equivalent ${ }^{[7]}$ of the $\mathrm{NUCu}-140$ steels is determined by

$$
\begin{aligned}
& \text { Carbon equivalent(wt pct) } \\
& \qquad \mathrm{C}+\left(\frac{\mathrm{Mn}}{6}\right)+\left(\frac{\mathrm{Cu}+\mathrm{Ni}}{15}\right)+\left(\frac{\mathrm{Cr}+\mathrm{Mo}+\mathrm{V}}{5}\right)
\end{aligned}
$$

where "Carbon equivalent" indicates the susceptibility of the steel to cracking during welding. A value equal to $0.4 \mathrm{wt}$ pct is obtained for the $\mathrm{NUCu}-140$ steels, which as seen in a Graville diagram (Figure 9), resides in zone I, indicating that the steels are weldable without concern for a brittle HAZ. The value for carbon equivalent is greater than the $0.3 \mathrm{wt}$ pct obtained for NUCu-100 but smaller than the values reported for HSLA-100 and HY100 in Reference 2. In addition to the excellent weldability and lack of a HAZ, the steel does not contain $\mathrm{Cr}$, leading to formation of $\mathrm{Cr}^{6+}$, a carcinogenic fume, during welding.

\section{Atom-Probe Tomography}

The nano-size $\mathrm{Cu}$-rich precipitates, because of their comparatively large $N_{V}$ values, are responsible for the increase in strength during aging (Figure 2). The source of the strengthening from small coherent $\mathrm{Cu}$-rich precipitates in steels, however, is unresolved and has been recently reviewed. ${ }^{[50]}$ The source of this controversy is possibly a result of a combination of a number of precipitation strengthening mechanisms include lattice mismatch, modulus mismatch, and chemical hardening. ${ }^{[51-57]}$ Also, when the dislocation enters the precipitate two partial dislocations are created that combine when the dislocation leaves the precipitate. Energy must be supplied to move the dislocation out of the precipitate.

The $\mathrm{Fe}$ content in the $\mathrm{Cu}$-rich precipitates, as measured in this investigation, is about 25 at. pct. ${ }^{[0]}$ Previous atom-probe studies of thermally aged $\mathrm{Fe}-\mathrm{Cu}-$ based alloys have consistently detected significant amounts of $\mathrm{Fe}$ in $\mathrm{Cu}$-rich precipitates about $2 \mathrm{~nm}$ in radius, in both binary $\mathrm{Fe}-\mathrm{Cu}$ alloys ${ }^{[20,58]}$ and multicomponent $\mathrm{Fe}-\mathrm{Cu}$-based alloys. ${ }^{[27,28,30,59]}$ Small-angle neutron scattering (SANS), ${ }^{[56,60]}$ using indirect methods that involve magnetic scattering for deconvoluting the precipitate composition, however, suggests a much smaller amount of $\mathrm{Fe}$ of up to 10 at. pct in the precipitates. We note that SANS provides precipitate compositions based on questionable assumptions, ${ }^{[61]}$ whereas the APT results are model independent. Additionally, the recent first-principles calculations by Liu et al.$^{[55]}$ finds that the shear modulus relevant for dislocation glide varies at absolute $0 \mathrm{~K}$ from a negative value of $20 \mathrm{GPa}$ for pure bcc $\mathrm{Cu}$ to a positive value of $78 \mathrm{GPa}$ for bcc Fe, with a zero value for compositions near 50 at. pct $\mathrm{Fe}$ and 50 at. pct $\mathrm{Cu}$. The results of this study predict that bcc $\mathrm{Cu}$ precipitates with $\mathrm{Cu}$-rich concentrations, in a binary $\mathrm{Fe}-\mathrm{Cu}$ alloy, are mechanically unstable, which is consistent with APT observations showing significant quantities of $\mathrm{Fe}$ in $\mathrm{Cu}$ precipitates with about 2-nm radius. ${ }^{[20,27,28,30,58,59]}$

Nickel and Mn spherical shell enrichment has been observed for model $\mathrm{Fe}-\mathrm{Cu}-\mathrm{Ni}$ and $\mathrm{Fe}-\mathrm{Cu}-\mathrm{Ni}-\mathrm{Mn}$ steels, ${ }^{[30,58,59,62-64]}$ but the concomitant enrichment in $\mathrm{Al}$ is a new result. Approximately equal proportions of $\mathrm{Ni}$ and $\mathrm{Al}$ in the spherical shell surrounding the $\mathrm{Cu}$-rich core at 100 hours of aging may possibly be related to formation of a B2 ordered intermetallic phase. This conclusion cannot be made on stoichiometry alone. Conventional XRD studies have proven inconclusive because of counting statistics limitations. Recent synchrotron radiation experiments on the similar NUCu170 steel at the Advanced Photon Source (APS), Argonne National Laboratory, however, has successfully identified the Ni-Al-Mn enrichment as a B2 crystalline structure. ${ }^{[65]}$ The segregation of $\mathrm{Ni}, \mathrm{Al}$, and $\mathrm{Mn}$ to the precipitate $/ \alpha-\mathrm{Fe}$ matrix heterophase interfaces may possibly slow growth and coarsening, which makes the steel less prone to weakening resulting from overaging of the precipitates.

The presence of a larger, 3-nm radius, precipitate heterogeneously nucleated at a GB consisting predominantly of equal quantities of $\mathrm{Ni}$ and $\mathrm{Al}$ indicates that precipitates of this stoichiometry are stable within this steel at this temperature. The composition of the precipitate is suggestive of a NiAl (B2 structure) precipitate with $\mathrm{Fe}, \mathrm{Mn}$, and $\mathrm{Cu}$ substituting for $\mathrm{Ni}$ and $\mathrm{Al}$ in presently unknown proportions. The presence of NiAl precipitates at a GB and Ni-Al-Mn enrichments at the heterophase interface of the $\mathrm{Cu}$-rich precipitates indicates that the driving force for homogeneous nucleation is not sufficient, at the given composition and thermal treatment, to obtain $\mathrm{NiAl}$ (B2) precipitates within the ferrite grains.

\section{SUMMARY AND CONCLUSIONS}

The details on the investigation of an essentially ferritic nanoscale precipitation-strengthened steel, NUCu-140 (140 designates the nominal yield stress in $\mathrm{ksi}$ ), are presented. The steel is derived from the United 
States Navy's current HSLA-100 steel by increasing the $\mathrm{Cu}, \mathrm{Ni}$, and $\mathrm{Al}$ concentrations and omitting $\mathrm{Cr}$ and $\mathrm{Mo}$.

1. The steel achieves a $965 \mathrm{MPa}$ yield strength, elongation-to-failure values greater than 15 pct, and good CVN absorbed impact-energy values as high as $74 \mathrm{~J}$ at $-40{ }^{\circ} \mathrm{C}$ by simple heat treatment of solutionizing (austenitizing) at $900{ }^{\circ} \mathrm{C}$, followed by a quench into water at room temperature, and subsequent aging for 2 hours at $550{ }^{\circ} \mathrm{C}$.

2. The increase in strength is derived from a large number density (approximately $10^{23}$ to $10^{24} \mathrm{~nm}^{-3}$ ) of $\mathrm{Cu}$-rich coherent precipitates containing $\mathrm{Fe}, \mathrm{Ni}$, $\mathrm{Al}$, and $\mathrm{Mn}$.

3. Segregation of $\mathrm{Ni}, \mathrm{Al}$, and $\mathrm{Mn}$ to the precipitate/ $\alpha$-Fe matrix heterophase interfaces of the $\mathrm{Cu}$-rich precipitates is observed at 24 hours of aging. This segregation becomes more distinct with further aging to 100 hours.

4. Heterogeneous nucleation of a larger, 3-nm radius, precipitate within a grain boundary is observed. The stoichiometry of the precipitate is suggestive of a NiAl (B2 structure) precipitate with Fe, Mn, and $\mathrm{Cu}$ substituting for $\mathrm{Ni}$ and $\mathrm{Al}$ in presently unknown proportions.

5. The HAZ formed within NUCu-140 steel plate during welding is ductile. The microstructure in the plate's HAZ is ferritic after welding. The hardness in the HAZ is reduced, however, because of possible overaging of the $\mathrm{Cu}$-rich precipitates. The steel's carbon equivalent, $0.4 \mathrm{wt}$ pct, indicates that the steel may be weldable without preheat or postheat.

\section{ACKNOWLEDGMENTS}

This research is supported by the Office of Naval Research (Grant No. N00014-03-1-0252), Dr. Julie Christodoulou, grant officer. Atom-probe tomographic analyses were performed at the Northwestern University Center for Atom-Probe Tomography (NUCAPT), and the LEAP tomograph was purchased with funding from the NSF-MRI (Grant No. DMR-0420532, Dr. Charles Bouldin, monitor) and ONR-DURIP (Grant No. N00014-0400798, Dr. Julie Christodoulou, monitor) programs. Additionally, the LEAP tomograph was enhanced in late April 2006 with a picosecond laser with funding from ONR-DURIP (Grant No. N0014-06-1-0539). This work made use of Central Facilities supported by the MRSEC program of the National Science Foundation (Grant No. DMR0520513) at the Materials Research Center of Northwestern University.

\section{REFERENCES}

1. A.P. Coldren and T.B. Cox: Laboratory DTR, 1986.

2. E.J. Czyrycka, R.E. Link, R.J. Wong, D.A. Aylor, T.W. Montemarano, and J.P. Gudas: Nav. Eng. J., 1990, vol. 102, p. 63.

3. S.K. Dhua, D. Mukerjee, and D.S. Sarma: Metall. Mater. Trans. $A, 2001$, vol. $32 \mathrm{~A}$, p. 2259.
4. S.K. Dhua, A. Ray, and D.S. Sarma: Mater. Sci. Eng. A, 2001, vol. 318 , p. 197.

5. T.W. Montemarano, B.P. Sack, J.P. Gudas, M.G. Vassilaros, and H.H. Vanderveldt: J. Ship Prod., 1986, vol. 2, p. 145.

6. A.K. Sinha: Physical Metallurgy Handbook, McGraw-Hill, New York, NY, 2003.

7. R.W.K. Honeycombe and H.K.D.H. Bhadeshia: Steels Microstructure and Properties, Arnold, London, 1996.

8. R.P. Foley and M.E. Fine: in Int. Conf. on Processing, Microstructure and Properties of Microalloyed and Other Modern High Strength Low Alloy Steels, A.J. DeArdo, ed., ISS and TMS, Pittsburgh, PA, 1991, p. 315.

9. R.P. Foley: Ph.D. Thesis, Northwestern University, Evanston, IL, 1992.

10. C.S. Smith and E.W. Palmer: Trans. AIME, 1933, vol. 105, p. 133.

11. C.H. Lorig: Metal Progr., 1935, vol. 27, p. 53.

12. C.H. Lorig and R.R. Adam: Copper as an Alloying Element in Steel and Cast Iron, McGraw-Hill, New York, NY, 1948.

13. J.L. Gregg and B.N. Daniloff: The Alloys of Iron and Copper, McGraw-Hill, New York, NY, 1934.

14. M.E. Fine, R. Ramanathan, S. Vaynman, and S.P. Bhat: in Int. Symp. on Low-Carbon Steels for the 90's, R.I. Asfahani and G. Tither, eds., TMS, Pittsburgh, PA, 1993, p. 511.

15. S. Vaynman and M.E. Fine: in Int. Symp. on Steel for Fabricated Structures, R.I. Asfahani and R.L. Bodnar, eds., AISI and ASM International, Cincinnati, OH, 1999, p. 59.

16. S. Vaynman, M.E. Fine, G. Ghosh, and S.P. Bhat: in Materials for The New Millennium, K.P. Chong, ed., ASCE, Washington, DC, 1996, vol. 2, p. 1551.

17. S. Vaynman, R.S. Guico, M.E. Fine, and S.J. Manganello: Metall. Mater. Trans. A, 1997, vol. 28A, p. 1274.

18. S. Vaynman, M.E. Fine, R.I. Asfahani, D.M. Bormet, and C. Hahin: in Microalloyed Steel, R.I. Asfahani, R.L. Bodnar and M.J. Merwin, eds., ASM, Columbus, OH, 2002.

19. S.R. Goodman, S.S. Brenner, and J.R. Low Jr.: Metall. Trans., 1973, vol. 4, p. 2363.

20. S.R. Goodman, S.S. Brenner, and J.R. Low Jr.: Metall. Trans., 1973, vol. 4, p. 2371.

21. M.S. Gagliano: Co-Precipitation of Copper and Niobium Carbide in a Low Carbon Steel, Northwestern University, Evanston, IL, 2002, p. 239.

22. M.S. Gagliano and M.E. Fine: Calphad, 2001, vol. 25, p. 207.

23. M.S. Gagliano and M.E. Fine: Metall. Mater. Trans. A, 2004, vol. $35 \mathrm{~A}$, p. 2323.

24. M.K. Miller: Atom Probe Tomography, Kluwer Academic/Plenum Publishers, New York, NY, 2000

25. T.F. Kelly and M.K. Miller: Rev. Sci. Instrum., 2007, vol. 78, p. 031101

26. D.N. Seidman: Annu. Rev. Mater. Res., 2007, vol. 37, p. 127.

27. D. Isheim and D.N. Seidman: Surf. Interface Anal., 2004, vol. 36, p. 569 .

28. D. Isheim, M.S. Gagliano, M.E. Fine, and D.N. Seidman: Acta Mater., 2006, vol. 54, p. 841

29. S. Vaynman, M.E. Fine, S. Lee, and H.D. Espinosa: Scripta Mater., 2006, vol. 55, p. 351

30. D. Isheim, R.P. Kolli, M.E. Fine, and D.N. Seidman: Scripta Mater., 2006, vol. 55, p. 35.

31. T. Watanabe: Tetsu-to-Hagané, 1975, vol. 61, p. 2456

32. R.A. Fournelle, E.A. Grey, and M.E. Fine: Metall. Trans. A, 1976, vol. 7A, p. 669.

33. C. Asada and T. Watanabe: Trans. JIM, 1968, vol. 9, suppl., p. 387.

34. S.C. Kolesar: Precipitation Processes in Fe-Base, Ferritic, $\mathrm{Ni}$-Al Alloys, Northwestern University, Evanston, IL, 1971.

35. H.A. Calderon: Development of BCC Fe Base Alloys with Coherent Precipitates, Northwestern University, Evanston, IL, 1983.

36. T.T. Tsong: Atom-Probe Field Ion Microscopy, Cambridge University Press, Cambridge, United Kingdom, 1990.

37. O.C. Hellman, J.A. Vandenbroucke, J. Blatz du Rivage, and D.N. Seidman: Mater. Sci. Eng. A, 2002, vol. 327, p. 29.

38. O.C. Hellman, J. Blatz du Rivage, and D.N. Seidman: Ultramicrosc., 2003, vol. 95, p. 199.

39. O.C. Hellman and D.N. Seidman: Mater. Sci. Eng. A, 2002, vol. 327 , p. 24

40. R.P. Kolli and D.N. Seidman: Microsc. Microanal., 2007, vol. 13, p. 272. 
41. M.K. Miller and E.A. Kenik: Microsc. Microanal., 2004, vol. 10, p. 336.

42. C.J. McMahon Jr.: Interface Sci., 2004, vol. 12, p. 141.

43. D.F. Stein and L.A. Heldt: in Interfacial Segregation, W.C. Johnson and J.M. Blakely, eds., ASM, Metals Park, OH, 1979.

44. M. Guttman and D. McLean: in Interfacial Segregation, W.C. Johnson and J.M. Blakely, eds., ASM, Metals Park, OH, 1979.

45. E.O. Hall: P. Phys. Soc., Ser. B, 1951, vol. 64, p. 747.

46. N.J. Petch: J. Iron Steel Inst., 1954, vol. 173, p. 25.

47. A.J. DeArdo: Int. Mater. Rev., 2003, vol. 48, p. 371.

48. A. Urakami and M.E. Fine: Scripta Mater., 1970, vol. 4, p. 667.

49. M.E. Fine, A. Tongen, and M.S. Gagliano: in Electron Microscopy: Its Role in Materials Research, The Mike Meshii Symp., J.R. Weertman, M.E. Fine, K. Faber, W. King, and P. Liaw, eds., TMS, San Diego, CA, 2003, p. 229.

50. M.E. Fine and D. Isheim: Scripta Mater., 2005, vol. 53, p. 115.

51. K.F. Russell and L.M. Brown: Acta Metall., 1972, vol. 20, p. 969.

52. E. Nembach: Particle Strengthening of Metals and Alloys, WileyInterscience, New York, NY, 1997.

53. T. Harry and D.J. Bacon: Acta Mater., 2002, vol. 50, p. 209.

54. S. Lozano-Perez, M.L. Jenkins, and J.M. Titchmarsh: Philos. Mag. Lett., 2006, vol. 86, p. 367.

55. J.Z. Liu, A. van de Walle, and M.D. Asta: Phys. Rev. B: Condens. Matter, 2005, vol. 72, p. 144109.
56. K. Osamura, H. Okuda, M. Ochiai, M. Takashima, K. Asano, M. Furusaka, K. Kishida, and F. Kurosawa: ISIJ Int., 1994, vol. 34, p. 359 .

57. A. Deschamps, M. Militzer, and W.J. Poole: ISIJ Int., 2001, vol. 41, p. 196.

58. G.M. Worrall, J.T. Buswell, C.A. English, M.G. Hetherington, and G.D.W. Smith: J. Nucl. Mater., 1987, vol. 148, p. 107.

59. P.J. Pareige, K.F. Russell, and M.K. Miller: Appl. Surf. Sci., 1996, vols. $94-95$, p. 362.

60. R. Kampmann and R. Wagner: in Atomic Transport and Defects in Metals by Neutron Scattering, C. Janot, W. Petry, D. Richter, and T. Springer, eds., Springer-Verlag, Berlin, 1986, p. 73.

61. M.E. Fine, J.Z. Liu, and M.D. Asta: Mater. Sci. Eng. A, 2007, vol. 463 , p. 271

62. K. Osamura, H. Okuda, K. Asano, M. Furusaka, K. Kishida, F. Kurosawa, and R. Uemori: ISIJ Int., 1994, vol. 34, p. 346.

63. T. Koyama and H. Onodera: Mater. Trans., 2005, vol. 46, p. 1187.

64. T. Koyama, K. Hashimoto, and H. Onodera: Mater. Trans., 2006, vol. 47 , p. 2765.

65. R.P. Kolli, Z. Mao, D.T. Keane, and D.N. Seidman: Appl. Phys. Lett., 2007, vol. 91, p. 241903. 